\title{
Gross National Happiness: meaning, measure and degrowth in a living development alternative
}

\author{
Ritu Verma ${ }^{1}$ \\ Tarayana Centre for Social Research and Development, Bhutan \\ Royal University of Bhutan, Bhutan \\ Out of the Box Research and Action
}

\begin{abstract}
Narrow framings of development founded on GDP growth have led to multiple ecological, social and political-economic crises across the world that threaten the survival of humans and socio-ecologies. With the growing recognition that an expansionist trajectory is no longer viable, a burgeoning global discussion on degrowth has emerged. However, a limited number of living societal solutions exist in response the emergent crisis of over-consumption, deep inequality and resource depletion. The driving development philosophy of Gross National Happiness from the Himalayan Kingdom of Bhutan is a unique living alternative that challenges GDP metrics. With societal happiness as the primary lens for viewing human progress within planetary limits, GNH places socio-cultural, political-economic and spiritual-ecological wellbeing at the center of national development. Based on five years of research in Bhutan, the article discusses GNH as a holistic development alternative in relation to degrowth. It highlights the role of local insights, conceptual innovations, tested methodologies and policy experiences in constructing a unique society, as well as how GNH influences other nations and global debates. The article reflects on challenges that GNH faces in negotiating powerful forces of globalization, geopolitical shifts, climate change and skewed relations of power and privilege that influence scholarship, development and knowledge production.
\end{abstract}

Keywords: Gross National Happiness, degrowth, holistic development, Bhutan

\section{Résumé}

Des cadrages étroits de développement fondés sur la croissance du PIB ont conduit à de plusieurs crises écologiques, sociales, politiques, et économiques à travers le monde qui menacent la survie des êtres humains et des socio-écologies. En reconnaissant qu'une trajectoire expansionniste ne soit plus viable, un débat mondial sur la décroissance est apparu. Cependant, un nombre limité de solutions sociales existent en réponse de la crise de surconsommation émergente, d'inégalités profondes, ainsi que de manque de ressources. La force dynamique de la philosophie de développement de l'indice du Bonheur National Brut (BNB) du Royaume Himalayen du Bhoutan est une alternative unique qui défie les métriques du PIB. En considérant le bonheur d'une société comme principal indice pour déterminer le progrès humain compris dans les limites planétaires, le BNB place le bien-être socio-culturel, politique, économique, spirituel, et écologique au centre du développement national. En se basant sur cinq ans des recherches réalisées au Bhoutan, l'article explore le BNB comme une alternative de développement holistique en ce qui concerne la décroissance. Le rôle des perspectives locales, des innovations conceptuelles, des méthodologies prouvées, et des expériences politiques dans la construction d'une société unique sont mis en évidence, ainsi que comment le BNB influence d'autres nations et des débats mondiaux. Cet article

\footnotetext{
${ }^{1}$ Dr. Ritu Verma, Adjunct Professor, Founder and Coordinator of the Wenner Gren Institutional Development Grant Bhutan, College of Language and Culture Studies, Royal University of Bhutan; Senior Researcher and Advisor, Tarayana Centre for Social Research and Development; Director of Out of the Box Research and Action; member of the International Expert Working Group (IEWG), Secretariat for a New Development Paradigm, Royal Government of Bhutan (RGoB); and Senior Researcher 2013-2014, Centre for Bhutan Studies and GNH Research, Thimphu, Bhutan. Email: rvermapuri "at" gmail.com. I am deeply grateful to Lisa Gezon, Susan Paulson, and members of dynamic 'Culture, Power, Degrowth' group, who heard and read earlier iterations of this article, including its presentation at the Culture, Power, Degrowth panel at the Anthropology and Environment section of the $114^{\text {th }}$ Annual Meeting of the American Anthropological Association, November 18-22 2015, Denver, USA. This is the third article in Lisa L. Gezon and Susan Paulson (eds.) 2017. "Degrowth, culture and power", Special Section of the Journal of Political Ecology, 24: 425-666.
} 
porte sur les défis envisagés par le BNB en négociant avec les forces prépondérantes de la mondialisation, les changements géopolitiques, le changement climatique, ainsi que les relations biaisées de pouvoir et privilège qui influent le travail académique, le développement et production de connaissances.

Mots clés : Indice du Bonheur National Brut, décroissance, développement holistique, Le Bhoutan

\section{Resumen}

Los estrechos marcos de desarrollo basados en el crecimiento del PIB han llevado a múltiples crisis ecológicas, sociales y político-económicas en todo el mundo que amenazan la supervivencia de los seres humanos y las socioecologías. Con el creciente reconocimiento de que una trayectoria expansionista ya no es viable, ha surgido una creciente discusión global sobre el decrecimiento. Sin embargo, un número limitado de soluciones sociales vivas existen en respuesta a la emergente crisis de sobreconsumo, profunda desigualdad y agotamiento de los recursos. La filosofía de desarrollo impulsor de Felicidad Nacional Bruta del Reino del Himalaya de Bhután es una alternativa de vida única que desafía métricas del PIB. Con la felicidad de la sociedad como el objetivo primordial para ver el progreso humano dentro de los límites planetarios, GNH sitúa el bienestar sociocultural, político-económico y espiritualecológico en el centro del desarrollo nacional. Basado en una investigación de cinco años en Bhután, el artículo discute GNH como una alternativa holística de desarrollo en relación con el decrecimiento. Se destaca el papel de los conocimientos locales, las innovaciones conceptuales, las metodologías probadas y las experiencias políticas en la construcción de una sociedad única, así como la forma en que GNH influye en otras naciones y en los debates mundiales. El documento reflexiona sobre los retos a los que se enfrenta la GNH en la negociación de poderosas fuerzas de la globalización, los cambios geopolíticos, el cambio climático y las relaciones de poder y privilegios sesgadas que influyen en la erudición, el desarrollo y la producción de conocimiento.

Palabras clave: Felicidad nacional bruta, decrécimiento, desarrollo holístico, Bhután

\section{Introduction}

Degrowth...is an open invitation for debate and action, an invitation to think and act outside the box. It is rooted in a broad and participatory social discussion about alternatives to the current unsustainable economy and on a profound understanding and preoccupation about the existing social and physical limits. (Sekulova et al. 2013:5)

Narrow framings of development founded on GDP growth have led to multiple ecological, social and political-economic crises across the world that threaten the survival of humans and socio-ecologies. As the Secretariat for a New Development Paradigm of the Royal Government of Bhutan notes, "...the doctrine of limitless growth has resulted in the destructive attempt to use the earth's resources to satisfy infinite wants" (SNDP 2013: vi). With the growing recognition that the dominant development trajectory is no longer viable, a burgeoning global discussion on degrowth has emerged (e.g. Demaria et al. 2013; Latouche 2009; Martinez-Alier et al. 2010). However, a limited number of alternative solutions exist in response the emergent crisis of endless patterns of consumption, deep inequality and resource depletion.

Gross National Happiness (GNH) from the Himalayan Kingdom of Bhutan is a unique and meaningful living development alternative that challenges the logic of GDP metrics. With societal happiness as the primary lens for viewing human progress within planetary limits, GNH places sociocultural, spiritual, political, economic and ecological wellbeing at the center of national development efforts and policies. This article provides a rare glimpse into the foundations of GNH. It argues that GNH and degrowth share key moral concepts and are congruent in many aspects of their critical diagnoses and prognosis of problematic growth-based paradigms such as GDP. However, while degrowth emerged as a theoretical idea and political slogan with social implications (Latouche 2003, 2009), GNH has been put into practice as a living alternative development approach, and hence, can provide important reflections for degrowth debates and social movements.

This article analyzes GNH as a holistic development alternative from a degrowth perspective. It begins by reviewing streams of influence of degrowth from a wellbeing lens, before elaborating GNH in its different manifestations. The information presented is based on field study of GNH over five years, including direct involvement in the development of a new development paradigm (RGoB 2012; SNDP 
2013), seven trips to Bhutan between 2012-2013, and three years of field research from 2014-2016. ${ }^{2}$ The methodology includes participant observation, observant participation (Moeran 2009), policy analysis, and interpretive and analytical approaches. In analyzing GNH, and its influence on other nations and global debates, I highlight lived experience, local insights, conceptual innovations, tested methodologies and policy experiences. The article also reflects on the challenges that GNH faces in negotiating climate change, powerful forces of globalization, geopolitics, and relations of power and privilege.

\section{Streams of influence: degrowth from the lens of happiness}

Originating in a belief in décroissance, or "reduction", degrowth is a response to growing concerns regarding the exponential and unsustainable economic growth that dominates thinking of what constitutes 'progress' or 'development' (Demaria et al. 2013). Although degrowth is not a stand-alone concept, theory or ready-made system it requires a different logic from the prevailing yet problematic imaginary of growth (Latouche 2009, 2003). It is a proposition for those "who want to outline the contours of an alternative project for a post-development politics" while opening up a "space for inventiveness and creativity of the imagination" (Latouche 2009: 9). It has origins in the Francophone décroissance movement, and critiques of modernity in 1930s France (Martinez-Alier et al. 2010). It has evolved into a global field of investigation, a social movement and an interpretive frame for scholars, academics and activists (Demaria et al. 2013).

Sustainable degrowth is "an equitable downscaling of production and consumption that increases human wellbeing and enhances ecological conditions at the local and global level, in the short and long term" (Schneider et al. 2010: 512). It draws from innovations in political-economic thought, including proposals for steady state economics, defined as "an economy with constant population and constant stock of capital, maintained by a low rate of throughput [flows of matter and energy (Daly 2008)] that is within the regenerative and assimilative capacities of the ecosystem." Degrowth differentiates itself from 'green' growth and the 'green' economy, which fails to break away from discourses and practices centered on economic growth as the goal of development (e.g. carbon trading and credits), and technocentric and reductionist forms of intervention (Cavanagh and Benjaminsen 2017). The contemporary degrowth movement brings together several streams of critical scholarship focusing on wellbeing, bio-economics, anthropology of development, democracy and justice (Demaria et al. 2013; Schneider et al. 2010). This article focuses on three overlapping domains pertinent to GNH: the disconnection between growth and wellbeing and happiness, followed by critiques of development, and applications of political ecology that further nuance the details of the disconnection.

The first area of scholarship questions growth-led development based on endless cycles and lifestyles of working, earning, selling, buying and consuming (Demaria 2013). Such growth models remain superficially focused on material wealth, while failing to acknowledge the importance of deeper meaning in life and values that respect wellbeing. There is strong reasoning and evidence to expand development from its narrow focus of GDP (O'Neill 2012). For instance, the Easterlin paradox demonstrates that a higher rate of economic growth, or increase in income, does not result in an increase in happiness over the long-term (Easterlin et al. 2010). ${ }^{3}$ Paulson argues that indicators of economic growth are used by scientists, politicians and development practitioners as a proxy for other intended changes, "reinforcing the assumption that rising GDPs automatically produce healthier, happier, and wiser citizens" (2017: 428). Weak empirical correlation and growing evidence of unequal exchange that enables highly inequitable accumulation, unsustainable growth and elite capture, calls into question whether development defined as economic growth is good for societies (ibid.). Hence, alternative development approaches become imperative in refocusing the aims of development towards factors that can bring about happiness and wellbeing.

\footnotetext{
${ }^{2}$ During trips in 2012-2013 the author was Gender and Governance Division Head and Strategic Leader, ICIMOD, and in 2012, lead organizer, Bhutan+10 International Conference on Gender and Sustainable Mountain Development (co-organized by the Ministry of Agriculture and Forests, the National Commission for Women and Children, RGoB); and working as a member of the IEWG for a New Development Paradigm, RGoB.

${ }^{3}$ A paradoxical relationship exists where the happiness-income relation may be positive in the short-term, but not in
} the long term (ibid.). 
A better understanding of subjective aspects of wellbeing provide important information about how development can be recalibrated towards quality of life, its determinants, and aspects beyond income and material conditions (Stiglitz et al. 2009). A growing body of research has yielded meaningful and reliable data on objective wellbeing, comprising health, education, political voice, activities/time use, personal security, economic security and social connections (ibid.), and subjective wellbeing, defined as life satisfaction, presence of positive feelings such as joy and happiness, and absence of negative feelings such as anger and sadness (Deiner 1984). The latter indicates that the breadth and depth of social relations and connections correlate strongly with happiness, more than money and fame (Helliwell and Putnam 2004). Other approaches to the study of happiness in relation to degrowth and GNH are: the "flourishing" approach (living well and realization of potential); the "hedonic" approach (balance between positive and negative emotions); and the "evaluative" approach (a person's subjective appraisal of how life is going) (O'Neil 2012; Thompson and Marks 2008).

A second relevant field of scholarship is the anthropological critique of development interventions focusing on institutional practices and broader terms of global economic and cultural integration in countries of the South (Mosse 2013). Such studies critically analyze development as a dynamic process involving power-laden discourses, policies, practices, institutions, and acts of brokerage and translation (Mosse 2013, 2005; Lewis and Mosse 2006; Rist 1997). They suggest that amidst the breadth and complexity of thought and practice, development is an elusive, heterogeneous and constantly changing field of meaning, and is therefore difficult to fix, define or order (Crush 1995). Nonetheless a hegemonic organizing concept of our time, it can be viewed as a "dominant problematic or interpretive grid" through which impoverished regions of the world are known to us, thus rendering a host of everyday observations intelligible and meaningful (Ferguson 1994: xiii). Through this grid, local populations in the South are assumed to have a common 'problem': they lack development (ibid.). Anthropologists of development shed light on this powerfully alluring narrative, often couched in discourses of practical and moral improvement (Moore 1993; Mosse 2013).They problematize the idea that solutions necessarily lie in advancing the goal of raising GDP, establishing modernity mirroring Euro-American lifestyles and institutions, and deploying technical interventions to solve what is assumed to be the 'technical problem' of poverty (Ferguson 1994). Exemplified in the infamous austerity of Structural Adjustment Programs of the 1980s, conditional finance of the 1990s promoting growth and markets in national Poverty Reduction Strategy Papers, to the new aid architecture and ethos of auditing (with its plethora of indicators, outcomes and logframes) forging compliance with international financial institutions (Mosse 2013), poverty is framed as a 'national' problem in narratives that mask global inequality and the political economy of capitalism (Gupta 2010). These trends in development practice over time illuminate the irrationality of the "neoliberal economic logic that selectively integrates into markets, reduces social protection, casualizes labour, and increases inequality and distributional conflict, among other ill effects of capitalism" (cited in Mosse 2013: 236, see also Comaroff and Comaroff 2001; Ferguson 2006; Greenhouse 2009; Robinson 2002). Such ill effects include widening inequalities in wealth, the failure to account for environmental and social and costs within the neo-classical economics of endless growth. One example is the growing phenomenon of land grabs, driven by transnational corporations in search for the "cheap" extraction and exploitation of natural resources in the South (Borras 2012; Verma 2014).

Third, drawing critical attention to the anthropogenic causes of environmental degradation and its interrelationships with policy (Blaikie 1989; Simon 2008), political ecology emerged as a field of scholarship in the 1970s, as a response to apolitical understanding of human-environmental relations that blamed problems on population growth, inappropriate technology and poor management (Peet et al. 2011). It critically engages post-structural concerns of the inter-related nature of power and knowledge (Verma et al. 2014), and considers the way the local and the global are mutually constituted through particular configurations of development, environment and political-economy that create and legitimize certain claims over others (Mackenzie 2010). In doing so, it focuses on the ways that struggles over material resources are simultaneously struggles over cultural meanings (Carney and Watts 1990; Moore 1993; Schroeder 1995; Verma 2009). Congruent with degrowth, political ecologists highlight the problematic effects of neoliberal policies, capitalist-centered growth, technocratic interventions and globalization and its fixation on production, consumerism and materialism through the commodification and exploitation of natural resources (Paulson 2014; Peet et al. 2011). A central argument is that market mechanisms externalize socio-cultural and environmental costs, values and meanings, together with 
long-term consequences and effects of actions associated with them, and have thus failed to protect forests, oceans, air and the climate (Peet et al. 2011). Further, economic growth, continued at currently unsustainable rates, threatens to increase economic liabilities and accelerate natural resource depletion, while the externalization of costs will shift to future generations, other sentient beings, and an increasing number of economically poor women, men and children across the globe (Schneider et al. 2010).

\section{In search of the elusive development alternative}

Based on evidence of persistent failure of development interventions to fulfill their intended goals (Ferguson 1994), and a host of unintended effects that make local conditions worse, some scholars have argued for the "end of development" (Esteva 2010; Sachs 1992). A central problem with this stance is that while critiques are insightful, the proposed alternatives to development tend to be weak, an afterthought, non-existent, and lacking lived experience (Verma 2015). Agrawal, suggests that such critiques are "empty" and insufficient in engaging constructively with real-life problems to which development is posed as a solution, as one "cannot replace something with nothing" (1996: 472). Arguing for the end of development is neither intellectually nor politically adequate, as the larger global inequalities that underpin it cannot be wished or relabeled away by calling for its demise (Ferguson 1999). Development did not bring into being the political-economic inequalities between nation-states. Rather, "development was laid on top of already-existing geopolitical hierarchies; it neither created north-south inequality nor undid it but instead provided a set of conceptual and organizational devices for managing it, legitimating it, and sometimes contesting and negotiating its terms" (Ferguson 1999: 248). While there is a danger that new institutions might not adequately contest power relations, a degrowth perspective offers avenues for challenging relations of capitalistic power that underlie development itself and shape its deployment, including GDP, neoliberal policies, market-driven solutions, over-consumption and materialism, and natural resource exploitation.

If one accepts that development is necessary for engaging in real-life problems of poverty, sustainability and inequality in the South, then the central issue is not getting rid of development per se, but defining 'development' within different cross-currents of debate. Within dominant narratives of development, complex political-economic and socio-cultural issues are reduced to narrow technical problems, often understood from a bio-physical and neoliberal economic lens. Understood this way, the level of 'development' of a nation is narrowly reduced to the size of its economy (Peet and Hartwick 2009), and development solutions impose market-oriented interventions to provoke growth at the cost of social, cultural and ecological concerns. Bearing these arguments in mind, the rare development alternatives that exist become important in terms of their innovations in conceptualization, practices, institutions and inherent challenges for moving beyond the predominance of a growth-based paradigm. Given the dearth of living examples of development alternatives, GNH from Bhutan provides a unique conceptual and practical development alternative that defies business as usual.

\section{Eight manifestations of GNH}

The Royal Kingdom of Bhutan is a valuable context for the study of a living development alternative from a degrowth perspective. A small land-locked country nestled in the Greater Himalayas, it has a population of 768,577 inhabitants and a land area of 38,394 $\mathrm{km}^{2}$ (NSB 2016). Isolated over many years, Bhutan has had limited and purposively controlled exposure to the outside world from its geographically remote location. It shed its isolationist policy in 1959 in reaction to Chinese invasion and occupation of Tibet, which generated fears about similar transgressions across its borders. Henceforth, political and development priorities became a function of national security concerns, sovereignty and self-reliance in response to the shift in the regional balance of power (Priesner 1999). The 1960s were characterized by the cautious opening up to the outside world politically and economically through the establishment of diplomatic ties with India and other countries, and admission to the United Nations in 1971. Without the colonial burden of other nations, it embraced modernization on its own terms, with an explicit focus on prosperity and happiness as the objective of development. It experienced wide-ranging socio-cultural impacts over a short period of time from this new exposure to the outside world. For instance, television and internet were first introduced as recently as 1999, with the powerful commercialoriented media that accompanies it. In 2008, Bhutan became a democracy, with the adoption of a 
constitution that explicitly ensures that "the State shall strive to promote those conditions that will enable the pursuit of Gross National Happiness" (RGoB 2008: article 9).

Bhutan has taken forward a distinctly indigenous vision of development - one that evolved from its unique demographic and historic circumstances (Priesner 1999). Rather than an "intellectual construct detached from practical experience", this approach resulted from the translation of a socio-cultural and spiritual consciousness into development priorities (ibid.: p. 27). The Himalayan Kingdom is best known for the articulation of an innovative alternative path, exemplified in GNH, as a development approach that values happiness and wellbeing. GNH can be considered many things at once, and I argue that it is manifest in eight forms, elaborated briefly below in relation to degrowth (Verma 2015, 2016a; Verma and Ura 2015).

Moral concept

GNH is a moral concept that underlies and influences other manifestations. It strives for the happiness of all human and sentient beings, which is critical for a sustainable and thriving environment. GNH aims for deeper, meaningful, morally-driven and long-term attainment of happiness, rather than temporary states and fleeting 'feel good' moods associated with the term (Thinley 2012; Verma 2016a, 2016b). It focuses on inner contentment, peace and non-attachment, rather than material comfort and fleeting pleasures alone. Collective happiness, concern and service towards others, and harmony with nature and all sentient beings, sets GNH apart from mainstream GDP-centric development concerned with an individualistic sense of happiness grounded in narrowly defined notions of material progress. Both GNH and the degrowth perspective challenge unchecked consumerism and the desire to buy, produce, build, employ and borrow, and they expose limits to all these activities (Martinez-Alier et al. 2010; Schneider et al. 2010). However, neither degrowth nor GNH can operate in a bubble, set apart from GDP, and a reduction in the latter is neither germane, nor a measure of degrowth or GNH. For both, if a GDP decline occurs, it is the result of particular societal choices, rather than a goal in itself (Schneider et al. 2010). Paulson argues that, rather than pursuing economic growth as a means to all good ends, it may be useful to focus efforts directly toward chosen outcomes of well-being, measured not in monetary terms, but in terms valued by individual socio-cultures (Paulson 2017).

\section{Guiding principles}

GNH, as a set of guiding principles for development, dates back to the unification of Bhutan in 1729, where the legal code by Zhabdrung Rinpoche declared: "if the Government cannot create happiness (dekid) for its people, there is no purpose for the Government to exist" (Ura et al. 2012a). Initially outlined in 1961 by the 3rd King of Bhutan, Jigme Dorji Wangchuck, it is upheld as a middle path between culture and modernization, to counter the homogenizing effects of globalization (Ura 2005). This historical legacy was succinctly placed at the heart of development in 1972 by the Fourth King, Jigme Singye Wangchuck, in response to a concern over problematic GDP metrics commonly used to guide development. He declared Bhutan's policy to achieve economic self-reliance, prosperity and happiness for Bhutanese people, whereby GNH is more important than GDP. The view that happiness takes precedence over income-centric growth is supported by research that money does not result in happiness over the long term (Easterlin 2010). Continuing this legacy in 2008, the Fifth King Jigme Khesar Namgyel Wangchuck declared GNH as a distinct and unique approach: it is development with values (Ura et al. in press).

\section{Conceptual framework}

The moral concept of GNH is elaborated through a unifying conceptual framework with four pillars. The GNH pillars translate the moral concept into strategic objectives for development in several ways. They are founded on the belief that_holistic development cannot be achieved by any of the pillars in isolation, and are accorded equal weight and are mutually supportive. They have shaped Bhutan's fiveyear development plans since 1961 , including the recent $10^{\text {th }}(2008-2013)$ and $11^{\text {th }}(2013-2018)$ plans that direct national policies and practices. As the pillars illustrate, GNH is well aligned with degrowth in terms of its goals of ecological sustainability, social equality and wellbeing, and the incorporation of subjective dimensions not captured in GDP (Schneider et. al. 2010). The sustainable and equitable socio- 
economic development pillar is founded on the principle that qualitative measures of the means and nature of economic activities, such as aspects of wellbeing including leisure time, care-giving activities, sleep time, etc., are as important as quantitative measures and results (Ura et al. in press). The conservation of the environment pillar rests on the principle that happiness is deeply connected to people's relationship with a healthy, vibrant and wholesome natural environment, where for example, both the quantity of forest cover as well as the quality of the forest are important. The pillar of good governance is about the form and power of institutions, as well as the motivational values that drive them. The pillar of cultural preservation and promotion takes a pro-active approach to culture that balances voluntary social responsibility with the recognition of virtue in indigenous culture and social relations. The cultural pillar, although still evolving in its efforts to recognize culture as dynamic and changing (Thin et al. 2013), distinctly sets GNH apart from other development conceptual frameworks, such as the Sustainable Development Goals (SDGs), that exclude culture (United Nations 2012).

\section{Index of measurement}

In order to foster and enable measurement of a holistic range of GNH values, the moral concept and conceptual framework is further translated into a multi-dimensional index of measurement (Ura et al. 2015). A domain-based framework has been developed, piloted and implemented by the Centre for Bhutan Studies and GNH Research (CBS) through the first nation-wide GNH survey in 2008 (with a prepilot in 2006), followed by surveys in 2010 and 2015. The index is elaborated through nine domains, including conventional development indices such as i) health, ii) education and iii) living standards. It also includes new domains encompassing iv) time use, v) good governance and vi) ecological diversity and resilience. Innovative domains are vii) psychological wellbeing, viii) community vitality and ix) cultural diversity and resilience (Ura et al. in press). The nine domains are elaborated through 33 clustered indicators that inform the survey questions (Figure 1). GNH conveys more fully the breadth and texture of peoples' lives than the standard welfare measure of GDP per capita, and dominant development indices like the Human Development Index (HDI) (Metz 2014; Ura et al. 2012a, in press). It is operationalized in ways that help to track progress over time, and determine policies (Ura et al. 2012a). Most relevant to this article, the operationalization of GNH into indicators of measurement responds to the interest of the degrowth community for the development of new, non-monetary indicators (including subjective indicators) to assess development in terms of holistic socio-cultural and environmental values (O'Neill 2012).

\section{Policy and project screening}

GNH indicators enable Bhutanese citizens to hold leaders accountable, evaluate whether government policies are effective and being fulfilled, and assess support for the conditions of wellbeing in relation to policy (Ura et al. in press). For instance, a comparison between the 2010 and 2015 survey findings reflect changes over time in response to public action and policy priorities, and highlight the strengthening or deterioration in the social, cultural, economic and environmental fabric (Ura et al. 2012a, 2012b). Further, GNH policy and project screening tools, based on the indicators, contribute to policy coherence of government programs and projects in terms of GNH principles (Ura et al. in press). They are used by government agencies such as the GNHC (Gross National Happiness Commission, Bhutan's Planning Commission) to determine whether they are aligned with GNH. For instance, the GNH policy screening tools were used to systematically assess the National Youth Policy and the National Forest Policy. Assessment of the National Human Resource Development Policy indicated that it was GNH-favorable and within the GNH screening tool threshold; while it was determined that the possibility of Bhutan's accession to the World Trade Organization (WTO) was not GNH-favorable (GNHC 2011). Thus, GNH indicators as evaluative tools that are consistent with degrowth are used to check whether programs are consistent with GNH and to create conditions for a coherent relationship between professed values and actual policies and projects. 


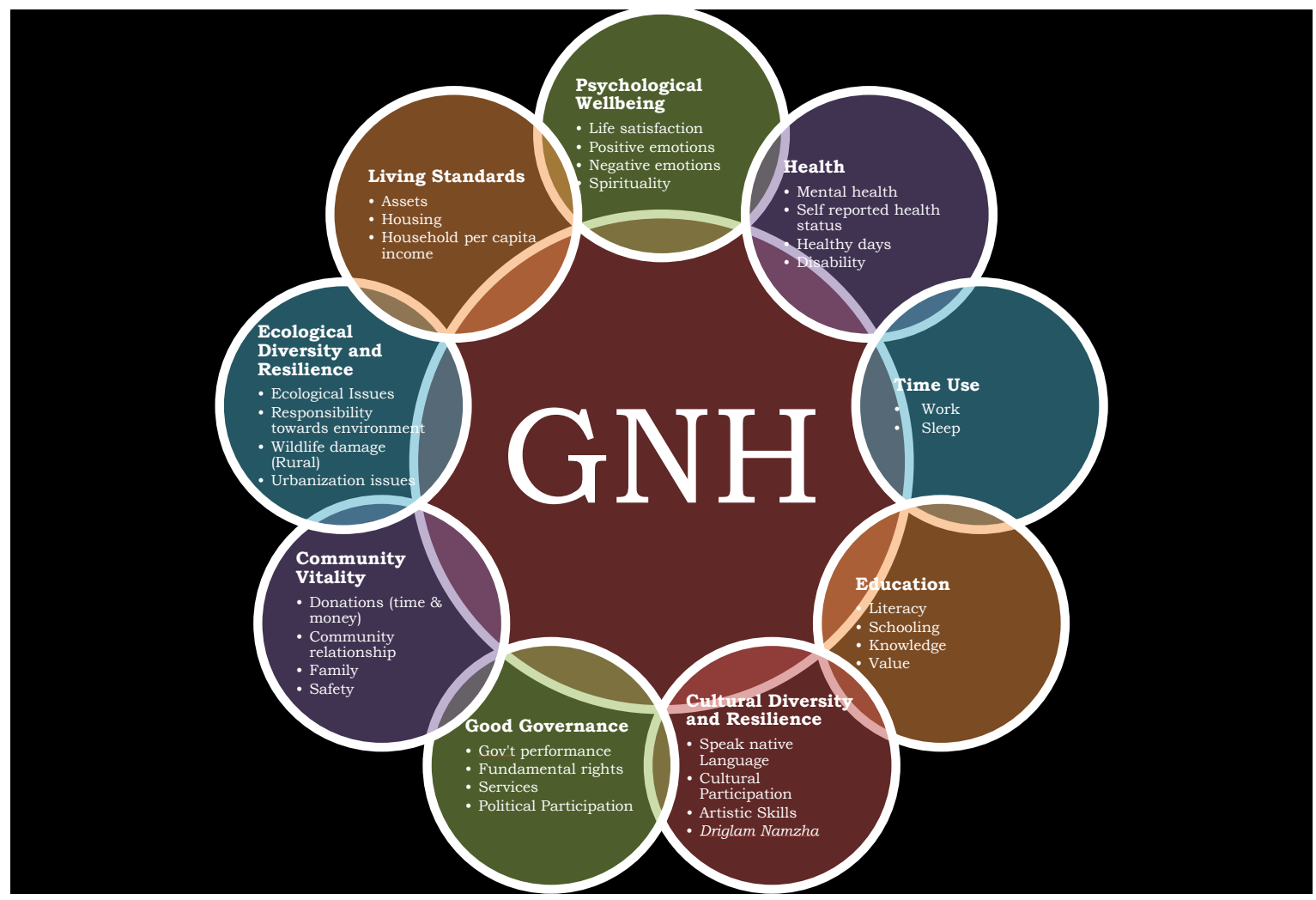

Figure 1: The 9 domains and 33 indicators of the GNH Index (Source: Ura et al. 2012a).

\section{Individual practice}

GNH is considered a collective responsibility, and is also translated into individual practice where citizens are expected to participate actively in their own development and that of the nation. This is supported through social and development services provided by the Bhutanese state such a free health care, education, extension services, paid maternity leave, etc., which illustrate the importance the country places on balancing economic with social, cultural, spiritual and environmental development. Such services are generated through development assistance negotiated with select donors, and by revenues generated from the taxation system similar to other socialist democracies such as Canada, Norway, Sweden and Denmark. GNH reflects the creation, support and provision of enabling conditions by the State for people to pursue wellbeing and attain happiness in sustainable and balanced ways (Ura et al. 2012a; Ura 2010).

While the State provides enabling conditions, individual citizens have a responsibility as active participants towards the attainment of both individual and collective wellbeing, as well as inner and outer conditions for happiness. Hence, the individual plays an active role in the achievement of happiness, including understanding the central tenets of GNH and the responsibility of embodying the behaviors, attitudes and practices that are central to achieving wellbeing. In Bhutan, the central monastic body plays an enabling role in this process, and new NGOs such as the GNH Centre also assist individuals, including foreign tourists, in practicing GNH.

\section{Global influence}

Although recent national efforts have focused GNH within Bhutan, it has had notable global influence, including integrating wellbeing into the SDGs and influencing other nations, scholars and practitioners about wellbeing and happiness as the ultimate goal of development. Most notably, in June 2012, the Royal Government of Bhutan (RGoB) set up the two-year Secretariat for the New 
Development Paradigm (SNDP) based on the principles of GNH. An International Expert Working Group (IEWG), composed of distinguished scholars from around the world representing a wide range of disciplines, was established to translate GNH into a new development paradigm and policy objectives for implementation beyond Bhutan. A high level meeting on wellbeing and happiness was convened at U.N. Headquarters in New York in April 2012, followed by a meeting of the IEWG in Bhutan in JanuaryFebruary 2013. An IEWG working group of distinguished researchers wrote background papers on the nine GNH domains (RGoB 2012), which provided inputs for the submission of the report Happiness: towards a new development paradigm by the RGoB to the U.N. General Assembly in December 2013 (SNDP 2013).

Further, six international GNH conferences were organized by CBS from 2004 to 2015 with a focus on development, practice, measurement, policy, and global transformation (Ura et al. in press). The cumulative effect has been the proliferation and spreading of GNH across the world. The concept has been adapted and integrated in terms of policy making, wellbeing and happiness measures, institutional contexts, and individual practice by countries such as Brazil, Japan, Thailand, Canada and France. In November 2015, an international association for the scholarly study of GNH was established. The crosspollination of GNH with other indigenous concepts that place wellbeing at the center of development is evident in reciprocal sharing and exchange visits with Ecuador and Bolivia (Buen Vivir), and the development of a bill that seeks an alternative measure to GDP by French parliamentarians. Similar to the degrowth movement, this cross-cultural exchange and learning demonstrates the necessity of the South influencing the North in terms of how development might be envisioned, practiced and altered away from unsustainable practices focused on GDP.

\section{The securalization of a Buddhist concept}

The focus on happiness-centered development evolved organically from historical and sociocultural features embedded in Buddhist and feudal values of a nation that was for many centuries isolated from the outside world (Priesner 1999). Contemporary Bhutan is predominantly a Vajrayana Buddhist nation that follows the Nyingma and Drukpa Kagyu schools of Buddhism (Kumagai 2015). Although socially engaged Buddhism and Buddhist moral and ethical engagement with happiness influences GNH in profound ways (Givel 2015; Tashi 2004; Verma 2016a, 2016b; Wangmo and Valk 2012), it is nonetheless a secular moral concept. The Buddhist notion of the inter-connectedness of all phenomenon influences GNH in its holistic vision of inter-dependence between humans and their environment, while its multi-dimensional nature attributes equal weighting to all domains (Wangmo and Valk 2012). In contrast to GDP-centric development that promotes economic growth to the exclusion of spiritual and mental development and subjective wellbeing (Thinley 2012), the holistic nature of GNH promotes the middle-path approach of maintaining a balance between the needs of the mind and the body (GNHC 2010; Verma 2016a, 2016b). Both degrowth and GNH aim to balance economic needs with spiritual and emotional needs, maximize wellbeing with minimizing suffering, nuance outer happiness with inner happiness, and material wellbeing with non-material wellbeing. Although the inter-relation between Buddhism and GNH is detailed elsewhere (Verma 2016a), GNH is the secularization of a Buddhist concept that places meaningful happiness and deeper values in life as its central purpose.

\section{GNH as a viable degrowth development alternative}

Latouche argues that a degrowth society is:

built on quality rather than on quantity, on cooperation rather than competition... humanity liberated from economism for which social justice is the objective... degrowth aims primarily at pointing out the insane objective of growth for growth. Degrowth is not negative growth, a concept that would be contradictory and absurd, meaning stepping forward while going backward. (Latouche 2003: 18).

As we move away from growth to a steady state economy, there is a need to change the way progress and development are measured, thereby abandoning GDP and replacing it with a holistic measure 
(Latouche 2004). The search is echoed by scholars and activists involved in the degrowth movement who call for viable alternatives that reflect its driving philosophy and social ideals, and that challenge mainstream development by re-examining the economic values that dominate affluent societies and recalibrating them towards the enjoyment of a good life and de-development (Hickel 2015; MartinezAlier et al. 2010). Such ideals accord greater attention to the way local environmental struggles and alternative approaches such as Buen Vivir engage development processes in innovative and transformative ways (Paulson 2014). This article argues that GNH is a viable living development alternative that not only exemplifies the central philosophical tenets of degrowth, but provides valuable opportunities and engaging challenges for its realization.

The emergence of GNH has been shaped by Bhutan's geopolitical position between two carbonemitting political-economic giants, its goal of ensuring self-reliance and sovereignty, and its unique history, spirituality and socio-cultural relations. GNH is Bhutan's middle path approach to development on its own terms. It is a living example of an indigenous approach. Given its similarities with degrowth, it provides valuable learnings, with potential applications in different locales around the world. Although largely overlooked in the degrowth movement, GNH's ambitious and groundbreaking approach is philosophically synergetic in degrowth's challenging of the economic-centrism of GPD, questioning unsustainable material attachment, contesting the disregard of environmental and socio-cultural 'externalities', and changing the dominant narrative of development to include all sentient beings. In this regard, GNH and degrowth share common values and conceptualizations. Both challenge dominant interpretations of the causes of environmental problems, and prevailing techno-centric, economicfocused and consumption-led responses to development (Paulson 2014). They are congruent in their goal of the pursuit of holistic development, wellbeing, ecological sustainability, social equity, non-violence and voluntary simplicity. They both embrace complexity of life, moving away from the reductionist approach of GDP, and towards multi-dimensional measures of what counts most: wellbeing and meaning in life.

GNH and degrowth have nuanced differences, which provide opportunities for learning and further dialogue. In order to shift the focus away from GDP, the degrowth movement will require the creation and promotion of indicators that measure what is meant by degrowth, including indicators for subjective wellbeing and happiness (O'Neill 2012). The GNH index of measurement has been operationalized in Bhutan, providing valuable data over time, and a fertile environment for knowledge sharing. While some degrowth scholars have called for a decrease in materialism and consumption in countries that exceed their ecological footprint, GNH has led by example, placing cultural and environmental policies at par with economic ones. Bhutan's ambitious pledge to remain carbon neutral and its success in absorbing three times more carbon that it emits, is an inspirational example (Verma 2016b). Through the domain of time-use, which can be disaggregated by gender, GNH responds to feminist critiques of GDP's exclusion and non-valuing of unpaid household, care and community work (Verma and Ura 2015). Further, its inclusion of innovative domains such as psychological wellbeing expands the meaning of development in ground-breaking ways (ibid.). GNH predates the degrowth movement by approximately three decades, and hence its engagement with the dominance of economiccentered development provides activists and scholars a wealth of experience to learn from. While degrowth provokes multiple understandings that sometimes render its aims unclear, the end goal of GNH is clear: happiness and wellbeing. Such clarity in GNH provides useful reflections for transformations in degrowth movements as they evolve and expand globally.

Degrowth is a voluntary transition towards a just and ecologically sustainable society that reduces the impact of the global economy to sustainable levels through a steady state economy, and increases equality within and between nations (Research and Degrowth 2010). It has catalyzed a growing movement bringing together practitioners, activists and academics from across the globe and from many disciplines interested in an alternative interpretive frame of development. GNH, in its eight manifestations, can be strengthened in many ways by this emergent movement, especially in terms crosspollination of ideas with a large body of like-minded thinkers. GNH can gain many insights from innovations that look for ways of reducing time allocated to and sharing labor, taking on board sustainable technologies, re-localizing economic activities (Martinez-Alier et al. 2010), integrating social justice and making gender equality more explicit. While GNH includes innovative domains such as timeuse and psychological wellbeing, it excludes gendered issues such as decision-making, room to maneuver, resistance and relations of power (Verma and Ura 2015). Also of use to GNH are critiques of 
partial truths problematized by degrowth analysis, and the way facts are constructed by science, technology and neoliberal economics, including reductionist world-views. Another significant way degrowth can strengthen GNH is through qualitative and ethnographic methodologies that explore meaning of life and wellbeing for differently positioned people, which currently represent a critical gap in GNH (Hoellerer 2010; Penjore 2013; Pommaret 2000; Ura et al. in press; Verma 2015).

In a globalized world dominated by GDP, GNH faces several challenges. The rate of sociocultural change and political-economic development of Bhutan, from isolation to active engagement with the world over a short period of time, cannot be emphasized enough. The country has experienced rapid changes within five decades of opening politically to the outside world, and a decade and a half of exposure to the powerful forces of a globalized media. These changes range from economic growth, increased engagement with international development processes and narratives, pressures on government to deliver material benefits in a newly formed democratic political system, and exposure to Western consumer lifestyles through television and social media, travel, education abroad, tourist interaction, advertising and other forms of cultural transmission (Hayden 2015: Walcott 2013). As a consequence, Bhutan has not been immune to capitalism, resulting in increased materialism and the emergences of a status-conscious consumer class with disposable income (Brooks 2013; Hayden 2015; Priesner 1999; Walcott 2011). Hence, in Bhutan, GNH exists side by side with the practice of GDP. An urgent issue is rapidly-changing cultural identities, especially experienced by youth who feel caught between two worlds, unable to relate to an older generation who grew up in a different set of political-economic circumstances in stark contrast to their own.

Despite the proliferation and evolution of national media, GNH is sometimes misunderstood, and its different manifestations conflated and prone to politicization. This is perhaps best exemplified by Bhutan's first two democratic elections in 2008 and 2012, where GNH became politicized (Hayden 2015). At the center of the GNH debate was the question of whether the approach should focus attention on improving wellbeing domestically only as challenges arise with the nation moving from least developed country to lower middle-income status, or continue advancing the alternative development path internationally. As the debate evolves-amid other debates on the nature of democracy, national identity, extent of economic growth, and the meaning of culture and affirmative action-the concept of the middle way provides the basis for deliberation, reflection and action. For GNH, its national or international engagement does not have to be an either/or situation. GNH can simultaneously focus on domestic issues, and be shared internationally for the benefit of all nations and sentient beings. Given the importance of the inter-related Buddhist concept dana, generosity towards others, sharing the central tenets of GNH with those who wish to learn and benefit from it is important. In order for this to happen, increased understanding of GNH is imperative, both nationally and globally. In the broader study of GNH, from which this article is a result, this has emerged as a critical issue. This article, and others that detail its eight manifestations and explore its inter-relation with gender, Buddhism, the Anthropocene and anthropological debates, are a humble effort in this direction (Verma 2015, 2016a, 2016b; Verma and Ura 2015).

\section{Conclusion}

As humans enter a new era in which we have drastically altered the climate and ecosystems across the globe and transgressed four of the nine planetary boundaries related to earth-system processes, the need for development alternatives is urgent (O'Neill 2012). GNH provides important alternative avenues for engaging with such pressing issues. The critical importance of increasing and deepening GNH consciousness for the benefit of human and sentient beings has never been more important. This article highlights how GNH manifests itself in eight different ways that are mutually supportive and translate the moral concept of a development alternative into reality. One outcome is that Bhutan is the only country in the world that is carbon neutral, absorbing three times more carbon than it emits (Verma 2016b; Nelson 2015). This is supported by its constitution that specifies sixty per cent of its land must be under forest cover in perpetuity (RGoB 2008). Also notable is its policy aim to rely predominantly on organic agriculture by 2020, its reliance on environmentally clean sources of revenue including run-ofthe-river hydro-power, high value-low impact tourism that limits the number of tourists into the country annually, and regulation of international development organizations, foreign capital, development aid 
and foreign experts within its borders. ${ }^{4} \mathrm{GNH}$ is a holistic development alternative that is not only congruent with degrowth, but a living example of it.

\section{References}

Agrawal, A. 1996. Poststructuralist approaches to development: some critical reflections. Peace and Change 21(4): 464-477.

Blaikie, P.M. 1989. Environment and access to resources in Africa. Africa 59(1): 18-40.

Borras, J. 2012. Global land grabbing and trajectories of agrarian change: a preliminary analysis. Journal of Agrarian Change 12(1): 34-59.

Brooks, J.S. 2013. Avoiding the limits to growth: gross national happiness in Bhutan as a model for sustainable development. Sustainability 5: 3640-3664.

Cavanagh, C. and T.A. Benjaminsen. 2017. Political ecology, variegated green economies, and the foreclosure of alternative sustainabilities. Journal of Political Ecology 24: 200-216.

Comaroff, J.L. and J. Comaroff (eds.) 2001. Millennial capitalism and the culture of neoliberalism. Durham NC: Duke University Press.

Carney, J. and M.J. Watts. 1990. Manufacturing dissent: work, gender and the politics of meaning in a peasant society. Africa 60(2): 207-241.

Crush, J. 1995. Introduction: imagining development. In Crush, J. Power of development. London: Routledge. Pp. 1-26.

Daly, H.E. 2008. Growth and development: critique of a Credo. Population and Development Review 34: 511-518.

Diener, E. 1984. Subjective well-being. Psychological Bulletin 93: 542-575.

Easterlin, R.A., L.A. McVey, M. Switek, O. Sawangfa and J.S. Zweig. 2010. The happiness-income paradox revisited. Proceedings of the National Academy of Sciences 107(52): 22463-22486.

Esteva, G. 2010. Development. In Sachs, W. (ed.) The development dictionary: a guide to knowledge as power. London: Zed. Pp. 1-23.

Ferguson, J. 1994. The anti-politics machine: "development," depoliticization, and bureaucratic power in Lesotho. Minneapolis: University of Minnesota Press.

Ferguson, J. 1999. Expectations of modernity: myths and meanings of urban life on the Zambian Copperbelt. Los Angeles: University of California Press.

Ferguson, J. 2006. Global shadows: Africa in the neoliberal world order. Durham NC: Duke University Press.

Givel, M. 2015. Mahayana Buddhism and gross national happiness in Bhutan. International Journal of Wellbeing 5(2): 14-27.

GNHC. 2010. Bhutan 2020: a vision for peace, prosperity and happiness. Thimphu: Gross National Happiness Commission.

GNHC. 2011. Gross national happiness policy screening tools. Powerpoint Presentation. Thimphu: Gross National Happiness Commission.

Greenhouse, C.J. (ed.) 2009. Ethnographies of neoliberalism. Philadelphia: University Pennsylvania Press.

Gupta A. 2010. The construction of the global poor: an anthropological critique. In Caillods, F. (ed.) The world social science report: knowledge divides. Paris: UNESCO. Pp. 13-16.

Hayden, A. 2015. Bhutan: blazing a trail to a postgrowth future? Or stepping on the treadmill of production? Journal of Environment and Development 24(2): 161-186.

Helliwell, J.F. and R.D. Putnam. 2004. The social context of well-being. Philosophical TransactionsRoyal Society of London Series B 359: 1435-1446.

\footnotetext{
${ }^{4}$ In Bhutan, it is common for development aid to be rejected due to conditionalities imposed by donors, and foreign experts to be relegated as advisors only (Priesner 1999).
} 
Hickel, J. 2015. Forget 'developing' poor countries, it's time to 'de-Develop' rich countries. The Guardian. 23 September.

Hoellerer, N.I.J. 2010. The use of qualitative and ethnographic research to enhance the measurement and operationalisation of gross national happiness. Journal of Bhutan Studies 23: 26-54.

Kumagi, S. 2015. Introduction. In Kumagi, S. (ed.) Bhutanese Buddhism and its culture. Kathmandu: Vajra Books. Pp. 1-6.

Latouche, S. 2003. Absurdité du productivisme et des gaspillages: pour une société de decroissance. Le Monde Diplomatique: 18-19.

Latouche, S. 2004. Degrowth economics. Le Monde Diplomatique. November 2004.

Latouche, S. 2009. Farewell to growth. Malden: Polity Press.

Lewis, D. and D. Mosse (eds.). 2006. Development brokers and translators: the ethnography of aid and agencies. West Hartford: Kumarian Press.

Mackenzie, F. 2010. Gender, land tenure and globalisation: exploring the conceptual ground. In D. Tsikata and P. Golah (eds.) Land tenure, gender and globalization: research and analysis from Africa, Asia and Latin America. Ottawa: International Development Research Centre. Pp. 35-69.

Martínez-Alier, J., U. Pascual, F.D. Vivien and E. Zaccai, 2010. Sustainable de-growth: mapping the context, criticisms and future prospects of an emergent paradigm. Ecological Economics 69(9): 1741-1747.

Metz, T. 2014. Gross national happiness: a philosophical appraisal. Ethics and Social Welfare 8(3): 218232.

Moeran, B. 2009. From participant observation to observant participation. In Ybema, S., D. Yanow, H. Wels and F. Kamsteeg (eds.). Organizational ethnography: studying the complexities of everyday life. London and New Delhi: Sage. Pp. 139-155.

Moore, D.S. 1993. Contesting terrain in Zimbabwe's Eastern Highlands: political ecology, ethnography, and peasant resource struggles. Economic Geography 69: 380-401.

Mosse, D. 2005. Cultivating development: an ethnography of aid policy and practice. London: Pluto Press.

Mosse, D. 2013. The anthropology of international development. Annual Review of Anthropology 42: 227-246.

Nelson, A. 2015. Bhutan has most ambitious pledge at the Paris Climate Summit. The Guardian. December 3.

NSB. 2016. Statistical year book of Bhutan 2016. Thimphu: National Statistics Bureau.

O'Neill, D.W. 2012. Measuring progress in the degrowth transition to a steady state economy. Ecological Economics 84: 221-231.

Paulson, S. 2014. Political ecology. In D'Alisa, G., F. Demaria and G. Kallis (eds). Degrowth: $a$ vocabulary for a new era. London and New York: Routledge. Pp. 45-48.

Paulson, S. 2017. Degrowth: culture, power and change. Journal of Political Ecology 24: 425-448.

Peet, R. and E. Hartwick. 2009. Theories of development: contentions, arguments, alternatives. New York: Guilford Press.

Peet, R., P. Robbins and M.J. Watts. 2011. Global nature. In Peet, R., P. Robbins and M.J. Watts (eds.). Global political ecology. London: Routledge: 1-48. Scribd

Penjore, D. 2013. The state of anthropology in Bhutan. Asian and African Area Studies 12 (2): 147-156.

Pommaret, F. 2000. Recent Bhutanese scholarship in history and anthropology. Journal of Bhutan Studies 2(2): 139-163.

Preisner, S. 1999. Gross national happiness: Bhutan's vision of development and its challenges. Gross National Happiness: A Set of Discussion Papers. Thimphu: Centre for Bhutan Studies and GNH Research.

Research and Degrowth. 2010. Degrowth: declaration of the Paris 2008 conference. Journal of Cleaner Production 18(6): 523-525.

RGoB. 2008. The constitution of the kingdom of Bhutan. Thimphu: Royal Government of Bhutan. 
RGoB. 2012. Defining a new economic paradigm. The report of the high-level meeting on wellbeing and happiness, 2 April, 2012, United Nations Headquarters, New York. Thimphu: Royal Government of Bhutan.

Rist, G. 1997. The history of development: from Western origins to global faith. London: Zed.

Robinson, W.I. 2002. Remapping development in the light of globalization: from a territorial to a social cartography. Third World Quarterly 23: 1047-71.

Sachs, W. (ed.) 2010[1992]. The development dictionary: a guide to knowledge as power. London: Zed.

Schneider, F., G. Kallis and J. Martinez-Alier. 2010. Crisis or opportunity? Economic degrowth for social equity and ecological sustainability. Journal of Cleaner Production 18: 511-518. Researchgate

Schroeder, R. 1995. "Gone to their second husbands": marital metaphors and conjugal contracts in the Gambia's female garden sector. Canadian Journal of African Studies 30(1): 69-87.

Sekkulova, F., G. Kallis, B. Rodriguez-Labajos and F. Schneider. 2013. Degrowth: from theory to practice. Journal of Cleaner Production 38: 1-6. Researchgate

Simon, D. 2008. Political ecology and development: intersections, explorations and challenges arising from the work of Piers Blaikie. Geoforum 39(2): 698-707.

SNDP 2013. Happiness: towards a new development paradigm: report of the Kingdom of Bhutan. Thimphu: NDP Steering Committee and Secretariat.

Stiglitz, J.E., A. Sen and J. Fitoussi. 2009. Report by the commission on the measurement of economic performance and social progress. Paris: Commission on the Measurement of Economic Performance and Social Progress.

Tashi, Khenpo P. 2004. The role of Buddhism in achieving gross national happiness. In Gross national happiness and development. Proceedings of the first international seminar on operationalization of Gross National Happiness. Thimphu: Centre for Bhutan Studies and GNH Research. Pp. 483-495.

Thin, T., R. Verma, and Y. Uchida. 2013. Culture, development and happiness. Report on Wellbeing and Happiness: contributions towards the RGOB's NDP report by IEWG members of the Wellbeing \& Happiness working group. Thimphu: Secretariat for the New Development Paradigm and the Centre for Bhutan Studies.

Thinley, J.Y. 2012. What is gross national happiness? Thimphu: Centre for Bhutan Studies and GNH Research.

Thompson, S. and N. Marks. 2008. Measuring wellbeing in policy: issues and applications. London: New Economics Foundation.

United Nations 2012. The future we want: resolution adopted by the General Assembly on 27 July 2012, A/RES/66/288. New York: United Nations.

Ura, K. 2005. The Bhutanese development story. Thimphu: Centre for Bhutan Studies and GNH Studies.

Ura, K. 2010. A proposal for GNH value education in schools. Thimphu: Centre for Bhutan Studies and GNH Research.

Ura, K., S. Alkire, T. Zangmo and K.Wangdi. 2015. Provisional findings of the GNH survey. Thimphu: Centre for Bhutan Studies and GNH Research.

Ura, K., S. Alkire, Z. Tshoki and K. Wangdi. 2012a. A short guide to Gross National Happiness index. Thimphu: Centre for Bhutan Studies.

Ura, K., S. Alkire, Z. Tshoki, and K. Wangdi. 2012b. An extensive analysis of GNH index. Thimphu: Centre for Bhutan Studies.

Ura, K., R. Verma, T. Phuntsho, R. Zangmo and D. Chopel. in press. Holistic development with values: CBS Strategic Research Agenda 2015-2024. Thimphu: Centre for Bhutan Studies and GNH Research.

Verma, R. 2009. Power, culture and development disconnect in the central highlands of Madagascar. Ph.D. Dissertation. London: School of Oriental and African Studies, University of London.

Verma, R. 2014. Land grabs in east and southern Africa, So what's new? Historical continuities, political disconnects and gender dispossessions. Feminist Economics 20(1): 52-75. 
Verma, R. 2015. Reflections from Bhutan: exploring gross national happiness as a holistic development alternative. Paper presented at the Center for India and South Asia Colloquium Series, UCLA, November 16.

Verma, R. 2016a. The eight manifestations of gross national happiness in Bhutan. Out of the Box Research and Action Working Paper. Thimphu: Out of the Box Research and Action.

Verma, R. 2016b. Climate change perspectives from Bhutan: unique engagement with the Anthropocene. Climate sciences and climate change from the perspective of the South Panel, Conference on Anthropology, the Weather and Climate Change, 27-29 May. London: RAI.

Verma, R. and K. Ura. 2015. Gender differences in GNH in Bhutan: critical analysis and reflection from the 2010 and 2015 GNH Surveys. Thimphu: Centre for Bhutan Studies and GNH Research. draft

Verma, R., P.M. Blaikie and J. Muldavin. 2014. New knowledge meets old problems: exploring disconnects in environmental research and policy in the Himalayas. Panel on rituals of development - the magic of a modernising project. Edinburgh: ASA Conference, June 19-22.

Verma, R., K. Ura, T. Phuntsho, T. Zangmo and D. Chopel. in press. Holistic development with values: centre for Bhutan studies and GNH research strategic agenda (2015-2024). Thimphu: CBS.

Walcott, S.M. 2011. One of a kind: Bhutan and the modernity challenge. National Identities 13(3): 253265.

Wangmo, T. and J. Valk. 2012. Under the influence of Buddhism: the psychological well-being indicators of GNH. Journal of Bhutan Studies 26: 53-81. 